\title{
Matkakirjallisuus ja identiteetti
}

Konferenssiraportti

Travel Writing, Cultural Exchange and Identity Construction -sektio European Society of Comparative Literature -yhdistyksen konferenssissa Ranskan Lillessä 29.9.2019

Sektion vastuulliset järjestäjät: Sandra Vlasta (Mainzin yliopisto) ja Leena Eilittä (Helsingin yliopisto).

Leena Eilittä 
ravel Writing, Cultural Exchange and Identity Construction

T -sektion tarkoitus oli kiinnittää huomiota matkakirjallisuuden välittämään moninaiseen tietoon etenkin yksilön ja yhteisön identiteetin muodostuksen kannalta. Sektion järjestäjät

Sandra Vlasta ja Leena Eilittä korostivat avauspuheenvuorossaan, että matkakirjallisuus välittää monipuolisesti tietoa paitsi matkoista myös niiden kirjoittajista niin yksilöllisessä kuin kollektiivisessa mielessä. Alfred Opitzin tutkimukseen vedoten he painottivat matkakirjoitusten kertojan roolia ja sen mahdollistamaa kommunikaatiota kirjoittajan ja lukijan välillä. Opitzin mukaan kertoja on kirjoittajan luoma minä, joka mahdollistaa erilaisten identiteettien luomisen ja lukijan identifikaation näiden identiteettien kanssa (Reiseschreiber 1997, 19). Kyse ei kuitenkaan ole pelkästään yksilöllisestä identiteetistä vaan prosessin myötä mahdollistuvat myös laajemmat identiteetit: kulttuurilliset, kansalliset ja sosiaaliset. Tämän takia matkakirjallisuudella on ollut huomattava yhteiskunnallinen vaikutus etenkin aikakausina, jolloin identiteettikysymykset ovat olleet tärkeitä; esimerkiksi sotien, konfliktien ja löytöretkien aikana aina antiikista lähtien tai kansallisvaltioiden syntymisen aikoihin 1800-luvulla (ja myöhemminkin) sekä esimerkiksi kommunismin jälkeen maissa, jotka saavuttivat itsenäisyytensä Neuvostoliitosta. Sektioon hyväksytyt esitelmät käsittelivät näitä matkakirjallisuuden identiteettiprosesseja monipuolisella tavalla.

\section{Lähi- ja kaukoperspektiivi}

Peter Arnds (Trinity College, Dublin) puhui esitelmässään "Mapping Literary Walks: Slow Travel and Identity Construction" ns. slow travel -ilmiöstä, jossa painottuu yksittäisen matkaajan konkreettinen kokemus. Arndsin mukaan esimerkiksi kävelyä kuvaavat tekstit ilmentävät tilannetta, joka kasvattaa kävelijän välimatkaa omaan sosiaaliseen ja poliittiseen yhteisöönsä ja sen velvoitteisiin. Samalla kävelijä tuntee tulevansa osaksi globaalia yhteisöä, ja usein häntä painaa huoli ympäristöstä ja kansainvälisestä politiikasta. Arndsin mukaan kävelyn hidastettu fyysisyys ja matkaajan marginaalisuus vaikuttavat identiteettiin tavalla, joka lisää poliittista valveutuneisuutta. Toisaalta Arnds painotti, että matkakirjallisuuden kuvaama kävely voi olla intensiivinen uusromanttinen kokemus. Hän viittasi tässä yhteydessä Percy Bysshe Shelleyn ja Mary Shelleyn seitsemänsataa kilometriä pitkä̈n kävelymatkaan, jonka he tekivät Pariisista Sveitsiin ilman rahaa. Esimerkkinä näistä ilmiöistä Arnds esitteli Sebaldin Die Ringer des Saturn: Eine englische Wallfahrt ja Arto Paasilinnan Jäniksen vuosiromaanit, Rory Stewartin Places in Between ja William Least Heat-Moonin Blue Highways-matkakirjat sekä Werner Herzogin Vom Gehen im Eis-päiväkirjan. Teoreettista lähtökohtaa hänen esitelmänsä sai muun muassa Michel de Certeaun (L'Invention de Quotidien, suom. Arkipäivän kekseliäisyys), Frédéric Grosin 
(Marcher, une philosophie, suom. Kävelyn filosofiaa) sekä Gilles Deleuzen ja Felix Guattarin (Mille Plateaux) ajatuksista.

Kun Arndsin esitelmän aiheena oli maanläheinen slow travel -matkakirjallisuus, Anja Burghardt (Münchenin yliopisto) haki korkealta tulevaa perspektiiviä esitelmässään "A 'bird's eye view' as a travelogue perspective". Burghardtin kohteena olivat Ryszard Kapuścińskin dokumentaariset matkakertomukset, joita tämä kirjoitti Neuvostoliitosta otsikolla Imperium (1993, suom. Imperiumi), ja jonka toinen osa on nimeltään "From the Bird's-eye View". Keskeisen Neuvostoliiton lisäksi Kapuściński matkusteli myös muun muassa Kaukasuksella ja Valko-Venäjällä palaten samoihin paikkoihin aina uudelleen. Burghardtin esitelmä kohdistui erityisesti teksteihin, joita Kapuściński oli kirjoittanut 1989-1991, toisin sanoen sosialismin jälkeiseen aikaan Itä-Euroopassa, ja hetkeen juuri ennen Neuvostoliiton hajoamista. Hänen mukaansa Kapuścińskin matkakirjoitukset ovat kiinnostavia erityisesti kollektiivisen identiteetin kannalta, koska suhde Puolan ja Venäjän/Neuvostoliiton välillä on ollut ongelmallinen aina Puolan jaosta lähtien. Kapuścińskin matkakertomuksissa näkyy selkeästi kertojan pyrkimys katsoa "imperiumia" yhtäältä suhteessa historialliseen taustaan, toisaalta nähdä Puola osana Euroopan traditioiden laajempaa yhteisöä. Burghardtin mukaan matkakirjan historiallispitoinen perspektiivi näyttää Neuvostoliiton koko laajuudessaan ja monimuotoisuudessaan, hetkellä jolloin kirjailijan ja tämän lukijakunnan oma maa kävi läpi poliittisen ja historiallisen muutoksen.

\section{Naisten matkakirjallisuus eilen ja tänään}

Kahdessa esitelmässä tarkasteltiin identiteettiä feministisen kysymyksenasettelun kautta sekä historian että nykyisyyden perspektiivistä. Martina Kopfin (Mainzin yliopisto) esitelmän aineistona olivat saksalaisen Sophie von La Rochen matkakirjoitukset, joita hän kirjoitti Sveitsistä (1784), Ranskasta (1785) sekä Hollannista ja Englannista (1786). Esitelmässään "Knowledge transfer and cultural exchange: Sophie von La Roche's travel diaries" Kopf näytti La Rochen pioneerin aseman naisena, jolla oli mahdollisuus tehdä matkoja Euroopan maihin ja kulttuureihin. La Roche oli kiinnostunut monimuotoisesti Euroopan kulttuurista ja luonnosta. Matkallaan Sveitsiin hän kävi esimerkiksi Mer de Glace -jäätiköllä sekä kulki Montversin solan läpi. Hänen kiinnostuksensa kohdistui kuitenkin ennen kaikkea eurooppalaisten naisten elämäntyyliin sellaisena kuin se ilmeni valistuksen aikakautena. La Rochen matkoista syntyneet päiväkirjat julkaistiin myöhemmin ja niitä pidettiin paitsi hänen omien kokemustensa kuvauksena myös pyrkimyksenä välittää tietoa etenkin muille naisille. Tagebuch einer Reise durch die Schweiz on omistettu La Rochen tyttärille Maximiliane Brentanolle ja Louise Möhnille, joille päiväkirja antoi mahdollisuuden mielikuvitusmatkoihin. Martina Kopfin mukaan La Roche vastasi näin odotuksiin, joita häneen kohdistettiin tuona aikana kirjoittavana naisena ja lasten äitinä. La 
Rochen matkakirjoitukset olivat uudistuksellisia myös muotonsa puolesta, sillä ne ilmentävät hybridisesti matkapäiväkirjan ja aikakauslehtiartikkelin yhdistelmää, joka aikanaan saavutti suosiota värikkyytensä takia.

Mirja Riggert (Freiburgin yliopisto) käsitteli esitelmässään nykyisten naisten matkakirjoituksia, joita on julkaistu blogien muodossa. Esitelmässään "Narrating the Self in Digital Travel Literature: Constructions of Feminine Identity in Travel Blogs" hän esitti, kuinka naisten kirjoittama matkakirjallisuus on muuttunut viime vuosikymmenten saatossa matkablogien kautta. Riggert osoitti esimerkkien avulla, kuinka feminiinisen kirjoittamisen ideat ohjaavat blogien kirjoitusta ja kollektiivista feminiinistä identiteettiä. Blogit tarjoavat Riggertin mukaan moninaisia hypertekstuaalisia ja vuorovaikutteisia kommunikaation muotoja kirjailijan ja lukijakunnan välillä ja luovat yhteisöllistä tunnetta, jonka perustana on yksilöllinen kokemus. Analysoimalla myös matkablogien intermediaalisia elementtejä Riggert halusi näyttää, kuinka toiseus on merkki kollektiivisesta feminiinisestä identiteetistä. Hän löysi jälkiä kansojenvälisestä solidaarisuudesta esimerkiksi tavassa, jolla kertova minä ilmaisee halunsa "nähdä Mongolia mongolialaisen naisen unelman kautta" (www.shewalkstheearth.com). Riggertin esittelemät BrownGirlsFlyn -blogit korostavat taas etnisesti sukupuolittunutta subjektiivisuutta, joka rakentaa yhdistävää identiteettiä etnisesti marginalisoitujen naisten välille tavalla, jonka tarkoitus on inspiroida naisia matkustamaan kaikkialla maailmassa. Toisaalta tällaista naistenvälistä yhteyttä voidaan muodostaa paradoksaalisesti myös korostaen matkan yksinäisyyttä ja eroa matkakohteiden asukkaisiin (www. slowlynorth.word-press.com). Riggertin mukaan feminiinisen solidaarisuuden kerronnalliset muodot ovat luonteenomaisia tämänhetkiselle digitaaliselle matkakirjoittamiselle. Feminiinisyyttä näyttämöllistämällä minäkertoja hakee omaa paikkaansa aiemmassa mieskeskeisessä matkustamisen ja matkakirjoittamisen maailmassa. Blogien tapa käsitellä lajin historiaan liittyvää maskuliinista symbolista järjestystä arvottaa samalla uudelleen feminiinistä etiikkaa ja sisältää piirteitä eron dynamiikkaa hakevista feministisistä teorioista sekä écriture féminine -kirjoitustyylistä. Uusilla digitaalisilla alustoilla julkaistut kulttuurillista vaihtoa kuvaavat kertomukset rakentavat Riggertin mukaan feminiinisyyttä tavalla, joka asettaa yksilön suhteeseen kollektiivin kanssa; toisaalta tämä positio näyttäytyy problemaattisena essentialisoidessaan feminiinisyyttä.

\section{Matkoja arabien historiaan}

Sektiossa oli peräti kolme esitelmää, jotka käsittelivät eri tavoin arabikulttuureita, näiden uskontoja sekä suhdetta länsimaisiin kulttuureihin. Anglaia Iankovskaia (Antropologian ja etnografian museo, Pietari) esitteli marokkolaisen oikeusoppineen Ibn Battutan kohtaamisia toiseuden kanssa matkoillaan, joita tämä oli tehnyt erityisesti Kiinaan ja Malayn saaristoon 1300-luvun puo- 
livälissä. Esitelmässään "Ibn Battuta, His Muslim Self and the Non-Muslim Other" Iankovskain kriittisen tarkastelun kohteena oli kysymys Ibn Battutan näkökulman universaalisuudesta ja kosmopoliittisuudesta, toisin sanoen hänen mahdollinen avoimuutensa itselleen vieraita kulttuureja ja uskontoja kohtaan. Kiinalla oli erityinen rooli Ibn Battutan matkoilla, sillä sinne saapuessaan hän jätti taakseen islamilaisen maailman. Sekä Kiinassa että Malayan saariston kuvauksissa hänen huomionsa olivat huolten ja epämukavuuden sävyttämiä; hän pyrki esimerkiksi välttämään ateriointia ei-muslimien kanssa ja asui vain paikallisten muslimien luona. Toiseuden kokemukselle näissä matkakirjoituksissa on kaksi lähdettä; yhtäältä se syntyy Ibn Battutan jo olemassa olevista käsityksistä ja toisaalta todellisista kohtaamisista, joita hän suhteutti omaan identiteettiinsä. Matkakirjoituksissaan hän tuntee yhteenkuuluvuutta erityisesti niiden arabien, Pohjois-Afrikan Maghreb-maiden asukkaiden, muslimien, sunnien, malikien ja valkoisten kanssa, jotka edustivat samaa sukupuolta ja ammattiryhmää kuin hän itse. Identiteettien repertuaari vaihtelee matkan sijainnin mukaan niin, että mitä lähemmäs Ibn Battuta tuli islamilaisen maailman rajoja, sitä enemmän hänen huomionsa alkoivat painottaa muslimien ja ei-muslimien vastakohtaisuutta kun taas muissa tilanteissa hänen huomionsa liittyivät islamilaisen maailman sisäisiin piirteisiin.

Jonathan Lawrence (Oxfordin yliopisto) esitteli toiseuden kohtaamisista syntyneitä identiteetin variaatioita Ilyas al-Mawsilin matkakertomuksissa. Esitelmässään "Multiple Identities: An Arab in the New World's Identity Manipulation" hän näytti, kuinka 1600-luvulla elänyt Ilyas al-Mawsili muovasi omaperäisellä tavalla arabi-identiteettiään tavoitteenaan tehdä itsestään avainhahmo espanjalaisessa Perussa. Lawrence painotti lähtökohtansa uutuutta Ilyas al-Mawsilia koskevassa tutkimuksessa, jossa on aiemmin tyydytty kuvaamaan tämän eksoottisia matkoja ja kohtaamisia aikansa merkkihenkilöiden kanssa, joita olivat esimerkiksi Ludvig XIV, Espanjan kuningatar ja Orléansin herttua. Lawrencen mukaan Ilyas al-Mawsili muovasi omaa identiteettiään suhteessa eurooppalaiseen kulttuuriin ja käytti tätä persoonaa välittävänä hahmona Espanjan ja Amerikan välillä. Euroopassa ja uuden maailman espanjalaisissa yhteisöissä vieraillessaan hän korosti kristillistä identiteettiään ja suorastaan kielsi etnisen ja kielellisen lähtökohtansa. Kommunikoidessaan alkuperäiskansojen kanssa hän sen sijaan nojasi arabi-identiteettiinsä ja otti välimatkaa sekä espanjalaisiin että amerikkalaisiin alkuperäiskansoihin. Lawrencen mukaan Ilyas al-Mawsili oli omaksumassaan kulttuurien välittäjän roolissa identiteetiltään hyvin vaikeasti määriteltävä hahmo. Tilannetta ei helpottanut hänen päätöksensä kirjoittaa matkakertomukset arabian kielellä. Lawrencen argumentti olikin, että Ilyas al-Mawsili käytti muuttuvaa identiteettiään kyetäkseen tekemään itsestään elinvoimaisen välittävän hahmon kahden ryhmän välillä. Tämä voi hänen mukaansa auttaa ymmärtämään laajemminkin tapaa, jolla varhaisen modernin ajan itäiset kristityt näkivät oman identiteettinsä muihin eurooppalaisiin verrattuna samaten kuin tietenkin rodun huomattavan merkityksen tänä aikana. 
Samuel Agbamu (Lontoon yliopisto) tarkasteli esitelmässään "Romanitá and nostalgia: Italian Travel Writing in Libya and Tunisia, 1905-1912" italialaisia kirjailijoita, jotka matkakirjoituksissaan puolustivat Italian valloitusta islamilaisessa Tripolitaniassa väittäen, että alueet kuuluivat Roomaan historiansa takia. Esimerkiksi Enrico Corradini, Domenico Tumiati, Giovani Pascolini ja Gabriele D’Annunzio kirjoittivat matkakirjoituksiaan romanitán kielellä, joka oli Rooman historiallinen kieli. Samuel Agbamun tarkemman analyysin kohteina olivat erityisesti Corradinin ja Tumiatin matkakirjoitukset. Tumiatin Nell'Africa Romana: Tipolitania (1905) kuvaa nostalgisesti pohjoisafrikkalaisia seutuja, joista ilmenee niiden kerran kuuluneen Italiaan. Nostalgian retoriikka leimaa myös merkittävän nationalistin Enrico Corradinin esseitä, jotka pohjautuvat hänen 1911 and 1912 tekemiinsä matkoihin. Molemmissa matkakuvauksissa Italian imperialismia kehystetään viittauksilla Rooman imperialismiin Afrikassa, kuten puunilaisiin sotiin, joita käytiin Tunisian-puoleisessa Karthagossa. Agbamun mukaan italialaisten kirjoittamista matkakirjoituksista ilmenee nationalistinen käsitys, että Italia voisi toipua ensimmäisen italialaisetiopialaisen sodan tappioista palaamalla roomalaisen Afrikan piirteisiin, ja tätä kautta kirjailijat myös rakensivat italialaista kolonialistista subjektia.

\section{Lopuksi}

Kaiken kaikkiaan sektion esitelmät loivat monipuolisen kuvan identiteetin kysymyksestä sekä historiallisessa että nykyajan perspektiivissä. Sektion esitelmät inspiroivat myös keskustelua, kysymyksiä ja kommentteja siihen osallistuneen yleisön keskuudessa. Vaikkakin aihepiirit vaihtelivat suurestikin, esitelmissä toistui kysymys ihmisen identiteetin ja laajasti ymmärretyn kontekstin suhteesta, mikä antoi keskustelulle kiinteyttä muodostavan punaisen langan. Yllättäviä ja uusia näkökulmia identiteetin kysymykseen toivat varsinkin ne esitelmät, jotka käsittelivät vähemmän tunnetun arabimaailman historiallisia matkakuvauksia. Mielenkiintoisen vertailukohdan näille esitelmille olisivat luultavasti antaneet Kauko-Idän matkakirjallisuutta analysoivat esitelmät, mutta valitettavasti näistä aiheista valikoituneet puhujat olivat estyneitä saapumaan konferenssiin.

Rohkaistuneena sektion onnistumisesta sen järjestäjät ovat suunnittelemassa sen pohjalta laajennettua julkaisua joko vertailevaan kirjallisuustieteeseen tai matkakirjallisuuteen erikoistuneessa tieteellisessä lehdessä.

\section{Lähteet}

Opitz, Alfred 1997. Reiseschreiber: Variationen einer literarischen Figur der Moderne vom 18.-20. Jahrhundert. Trier: Wissenschaftlicher Verlag Trier 